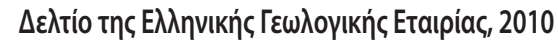

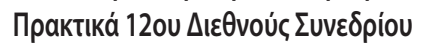

Пátpa, Máıoç 2010
Bulletin of the Geological Society of Greece, 2010

Proceedings of the 12th International Congress

Patras, May, 2010

\title{
CONTRIBUTION TO THE LATE NEOGENE STRATIGRAPHY OF THE ANCIENT GORTYS AREA (SOUTHERN CENTRAL CRETE, GREECE)
}

\author{
Bellas S. ${ }^{1}$ and Keupp H. ${ }^{2}$ \\ ${ }^{1}$ Ministry of Environment, Urban Planning \& Public Works (YPEXWDE), General Division \\ of Quality Control, GGDE/KEDE/ D14a, Piraeus 166 Str., GR-11854 Athens, Greece. \\ drbellas@zedat.fu-berlin.de \\ ${ }^{2}$ Freie Universität Berlin, Fachbereich Geowissenschaften, Institut für Paläontologie, \\ Malteserstr.74-100, Berlin, Germany, keupp@zedat.fu-berlin.de
}

\begin{abstract}
Most of the basal Neogene sediments of Crete Island (South Aegean Sea) were unconformably deposited during synsedimentary extensional tectonics and subsequent transgression on the basement. This work mainly focuses on the marine stratigraphy of south central Crete and specifically on the sedimentary deposits of the Gortys subbasin-area located in the basin of Messara. Four selected profiles north of Gortys ancient ruins (Heraklion Province) are lithostratigraphically presented. Profiles Gortys-1 and -2 (combined to one: 1+2) represent the basal Neogene deposits (older strata-commence of sedimentation) and are interpreted as of fluviatile to lagoonal origin, while profiles Gortys-4 and 4 a are considered the younger, marine development of the Gortys subbasin. Between profiles -4 and -4a are developed evaporites of the Messinian Salinity Crisis (MSC). Profiles are biostratigraphically studied and correlated on the basis of either identified macrofossils or calcareous and siliceous nannofossils. The recorded assemblages range in age from Serravallian-Tortonian to Messinian and Zanclean respectively. The good preservation and abundance of the fossil phytoplankton establishes a well-constrained biostratigraphic framework, which will further contribute to the understanding of the evolution of the Messara sedimentary basin.
\end{abstract}

Key words: Biostratigraphy, calcareous nannofossils, Gastropods, Miocene, Pliocene, Gortys, Messara, Crete, Greece.

\section{Introduction}

It is generally believed, that southward retreat of the trench in the Hellenic Arc System induced the arc migration, giving subsequently birth and shape to the modern Hellenic Arc System configuration (Wortel \& Spakman, 1992). The Aegean Sea extension (mainly at the southern part of it) and the southward movement of Crete Island were both caused by the rollback effect of the slab and broadly the subduction zone (Le Pichon, 1982; Meulenkamp et al., 1994). According to the later authors, this rollback process is believed to start about 12 my ago. In addition, the active tectonics deformation of the Aegean region is dominated not only by extensional but by combined strike-slip motions and compressional tectonics as well (Jackson, 1994; Meulenkamp et al., 1994). The concentration of slab pull forces causes a pattern of subsidence with development of depocenters and uplift migrating along strike. Subsequently, it prevailed a maximum crustal thinning and subsidence 
in the region of Cretan Sea (mainly of Neogene age, but it continues nowadays as well), which produced the back-arc basin(s) at the north of Crete as it was firstly suggested by studies of Makris (1978), Angelier et al. (1982) and Wortel \& Spakman (2000).

Presumably, the Neogene basins of Crete are generally considered the result of the prementioned subsidence and subsequent extension. Two successive marine sedimentation cycles (of Miocene and Pliocene age respectively) were originally distinguished on the island (Christodoulou, 1963; Meulenkamp et al., 1979; Frydas \& Keupp, 1996). A third cycle representing the Pleistocene transgression known from Psarianos (1961), was documented by calcareous nannofossil stratigraphy by Keupp et al. (1994) and Keupp \& Bellas in collab. with Frydas \& Bartholdy (2000).

The present work contributes to the completion of previous stratigraphical investigations in the south part of central Crete (Messara plain) and it is particularly focused in the marine sedimentary record of the Gortys subbasin (upper facies: profiles Gortys-4 and -4a), its biostratigraphy and relative age estimation of deposition based on calcareous nannofossils. A rather rough description of the lower and middle facies (fluvial to lagoonal) will be presented (profiles Gortys-1 \& -2), since a detailed analysis is under progress and it is far beyond the scope of this study [Demske, Keupp \& Bellas (in prep.)]. Furthermore, the reliability of some known biohorizons of nannofossils has been evaluated along the studied sections and their applicability concerning the biochronological correlation in the eastern Mediterranean Sea is commented.

\section{Geological setting}

The study area is found on Crete Island, Heraklion Province (Fig. 1). The Miocene-Pliocene deposits of Heraklion are considered among the most extended of Crete. Two wide fault zones or systems, developed relative perpendicular to each other, tectonically control the configuration of Heraklion Neogene Basin of central Crete. The first, adjacent to Heraklion city, is running in the N-S direction and represents a shoal, while the second segment situated to the south of Heraklion, produced the Messara fault-trough along the E-W direction (Delrieu et al., 1991; 1993) and it is bordered to the south by the Asteroussia Mountain range. Further tectonic data on central Heraklion for Late Pliocene to Recent are given in Papanikolaou \& Nomikou (1998), Fassoulas (2001), Ten Veen \& Kleinspehn (2003), Peterek \& Schwarze (2004), Hinsbergen \& Meulenkamp (2006) and recently by Papanikolaou \& Vassilakis (2009). The later authors propose that formation of the Messara supra-detachment basin in Middle Miocene time is related to a south dipping extensional detachment fault of the main E-W trending zone (tectonic horst).

Since there is very extensive literature concerning the lithostratigraphy and micropaleontology of Crete, the authors refer to Keupp \& Bellas in collab. with Frydas \& Bartholdy (2000) and for central Crete to Frydas et al. (2008), which include most of relative references. The prolongation of Heraklion Basin to the South and southwest of central Crete is called Messara Basin or Plain. Previous micropaleontological studies on this area like Zachariasse (1975), Jonkers (1984), Theodoridis (1984), Driever (1988) and Frydas \& Bellas (2009) were focused on isolated outcrops and/or cores. Frydas (1985, 1987, 1990, 1999, 2004) and Frydas et al. (1994) concentrated much of his Neogene stratigraphical research in the central Crete (Heraklion Basin) using calcareous and siliceous fossils. Preliminary biostratigraphic data concerning the NE Mires area in Messsara have been published by Bellas \& Keupp (2004). Among other authors, Drinia et al. (2005) and Koskeridou (2006) reported on central Crete benthic and planktonic Foraminifera and Mollusc issues of Pliocene age (Atsipades section, eastern Messara Basin). Brachert et al. (2006), Reuther et al. (2006) and Mertz-Kraus et al., (2009) refer to Tortonian-Messinian age shallow-marine clastics and carbonates with exceptionally well reef-growth from Messara, while recently $\alpha$ large part of the Messara marine stratigraphy was investigated by Frydas et al. (2008). 


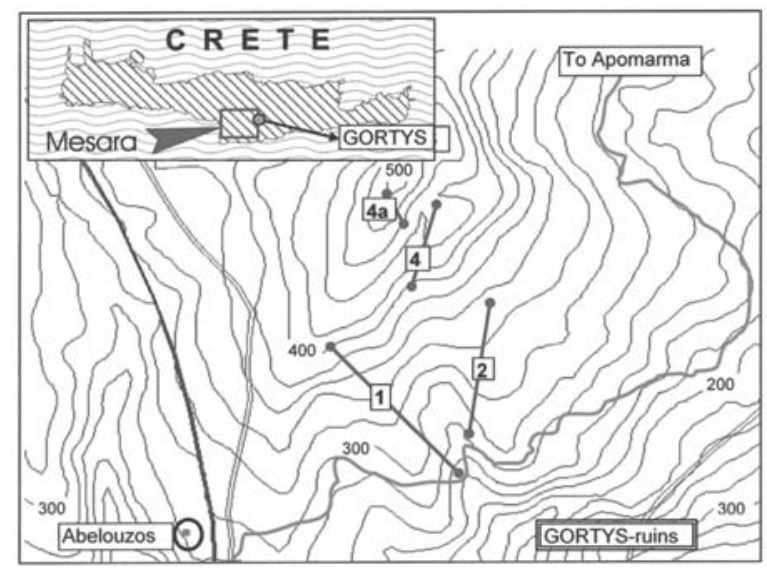

Fig. 1: Map with the location of the studied profiles (1,2,4 and 4a) in the Gortys subbasin (NW of ancient Gortys ruins, Messara, Crete Island, Greece. Contour interval 20m. Scale 1:50,000 (IGME, 1984 and Jarvis et al., 2008, SRTM digital elevation data slightly modified).

\section{Methods}

\subsection{Geographical location}

For the location of the studied sections it was used the Geological Map of IGME (1984), sheet "Tymbakion" (scale 1:50,000) and satellite data (SRTM digital elevation data, Jarvis et al., 2008). All studied outcrops are situated within a small gorge, running along a NNW-SSE direction and are located at the eastern part of Mesara Graben, to the N-NW of Agii Deka and to the N-NE of Abelouzos villages respectively, near the main street driving from Abelouzos to Apomarma, at ca. 1.2 $\mathrm{km}$ after the former village to the west. Further to the south, the ancient Gortys acropolis is to be seen, where the names of the outcrops come from [Gortys: The ancient city-acropolis of Gortys was founded and well developed between the $11^{\text {th }}$ and $8^{\text {th }} \mathrm{c}$. BC (Geometric Period) in the plain-basin of Mesara (Central Crete)] (Fig. 1).

\subsection{Studied Material - Methods}

During fieldwork, originally sediments of two outcrops to the west (Gortys-1) and east (Gortys2) flank of the gorge were lithostratigraphically studied. They found to be very well correlative, therefore they were combined in one profile presented in this study (Gortys-1+2: basal and middle part). The other two studied outcrops (representing the marine record) are individually described (Gortys-4 and -4a: upper part). Decompaction of sediment was not taken into account. Fifty-four (54) samples in total collected and laboratory processed; thirty-one of them (Gortys-1) proved nannofossil free, while twenty-three samples taken from Gortys-4 and -4a sections provided useful biostratigraphic data. Smear slides preparation of soft sediment (mainly sandy marls) followed standard techniques. Micropaleontology was based on calcareous nannofossils identification under normal light microscope (LM at magnifications of ca. 1000x). A quantitative and subsequently semiquantitative study of them has been also performed. Quantification of species (counting 300 individuals per sample -i.e. smear slide-) is presented in Tables 1 and 2 for each section, based on the following pattern: $\mathbf{A}($ Abundant $)=>20 \%, \mathbf{C}($ Common $)=10-20 \%, \mathbf{F}(\mathrm{Few})=$ $4-10 \%, \mathbf{R}($ Rare $)=1-4 \%$ and + for Present. Reworking is shown by r. Biostratigraphic schemes 
used are the «standard» zones of Martini (1971) (NN) and Okada \& Bukry (1980) (CN), the Mediterranean Nannoplankton Zonation for Neogene (MNN) of Rio et al. (1990) and those of Raffi \& Flores (1995) emended by Fornaciari (2000). Taxonomy, additional useful bioevents and their paleomagnetic position and biochronological calibration are based on Theodoridis (1984), Perch-Nielsen (1985), Martini \& Müller (1986), Driever (1988), Flores et al. (1992), Young et al. (1994), Berggren et al. (1995), Schackleton at al. (1995), Sprovieri et al. (1996), Rio et al. (1997), Negri \& Villa (2000), Van Couvering et al. (2000), Lourens et al. (2004), Raffi et al. (2003, 2006) and Morigi et al. (2007).

\section{Results}

\subsection{Lithostratigraphy-facies}

The Gortys subbasin is built by a few minor horst and graben structures. Based on main sedimentary facies, this subbasin deposits can be distinguished into three parts, the lower (a), middle (b) and upper (c). The strata of the lower part rest uncomfortably on the Preneogene basement. They are mainly representative by (a) fresh-water deposits and range from (a1) fluviatile (at the base), with various types of conglomerates and sandstones in alternation with mudrocks, to (a2) lacustrine mudrocks with non-marine gastropods fauna and a coal layer at the top. There follow strata of the middle part, possibly lagoon in origin (b), starting with a stacked Oysters (Crassostrea sp.) bank. Further upwards, follow mudrocks bearing marine gastropods (b1) and strata barren of macrofossils (b2), while at the upper part (c) a well-developed thick marine succession dominates the latter being indicative of a marine transgression with hemipelagic character (c1). After a few covered meters with chaotic Evaporites (d: Messinian Salinity Crisis, MSC), a new but not as thick as previously, shallow-water facies marine succession is developed (c2), which finally closes deposition in the subbasin.

\subsubsection{Combined Profile Gortys-1+2}

As prementioned and based on field work and the descriptions of two outcrops at the left and right flank of the Gortys gorge structure (old subbasin), we could reconstruct a composite profile for the lower (fresh-water: fluvial to lacustrine) and middle (lagoon) sedimentary facies (Gortys-1+2). This succession comprises ca. 63.0 metres (m) in thickness (Fig. 2).

Sedimentation began with fresh-water deposits (facies a). Various fluvial deposits (a1) rest on the preneogene basement. They consist of alternations by medium-bedded conglomerates (an exceptionally useful stratigraphic horizon of conglomerate which measures $3.75 \mathrm{~m}$ in thickness is present near the base of both flanks), green-grey pelites (mudstones) with fine to medium bedded clayey to silty sandstones, coarse-grained sandstones (indurate or not) and a few concretions layers in between. A conglomerate bed of $4.0 \mathrm{~m}$ in thickness completes the fluvial facies at the top, which presents a total of $29.0 \mathrm{~m}$ in thickness. Lacustrine deposits (a2) overlay the conglomerate. They are mainly consisted of green-grey mudstones $(5.80 \mathrm{~m}$ thick) and a lignitic layer of $0.40 \mathrm{~m}$ in thickness. A rich limnic gastropods fauna dominated by Potamides bidentatus accompanied by Ancilla sp. and Natica millepunctata recovered from these strata.

The following upwards succession is considered of lagoonal origin (facies b). It comprises $27.80 \mathrm{~m}$ in thickness and starts with a $0.80 \mathrm{~m}$ thick stacked Oysters bank (Crassostrea sp.), overlying by $5.0 \mathrm{~m}$ of grey mudstones bearing a rich marine gastropod fauna, like Arca (Anadara) spp., Cerithium sp., Conus (Conulithus) dujardini, Dentalium (Antale) fossile, Natica millepunctata tigrina, 

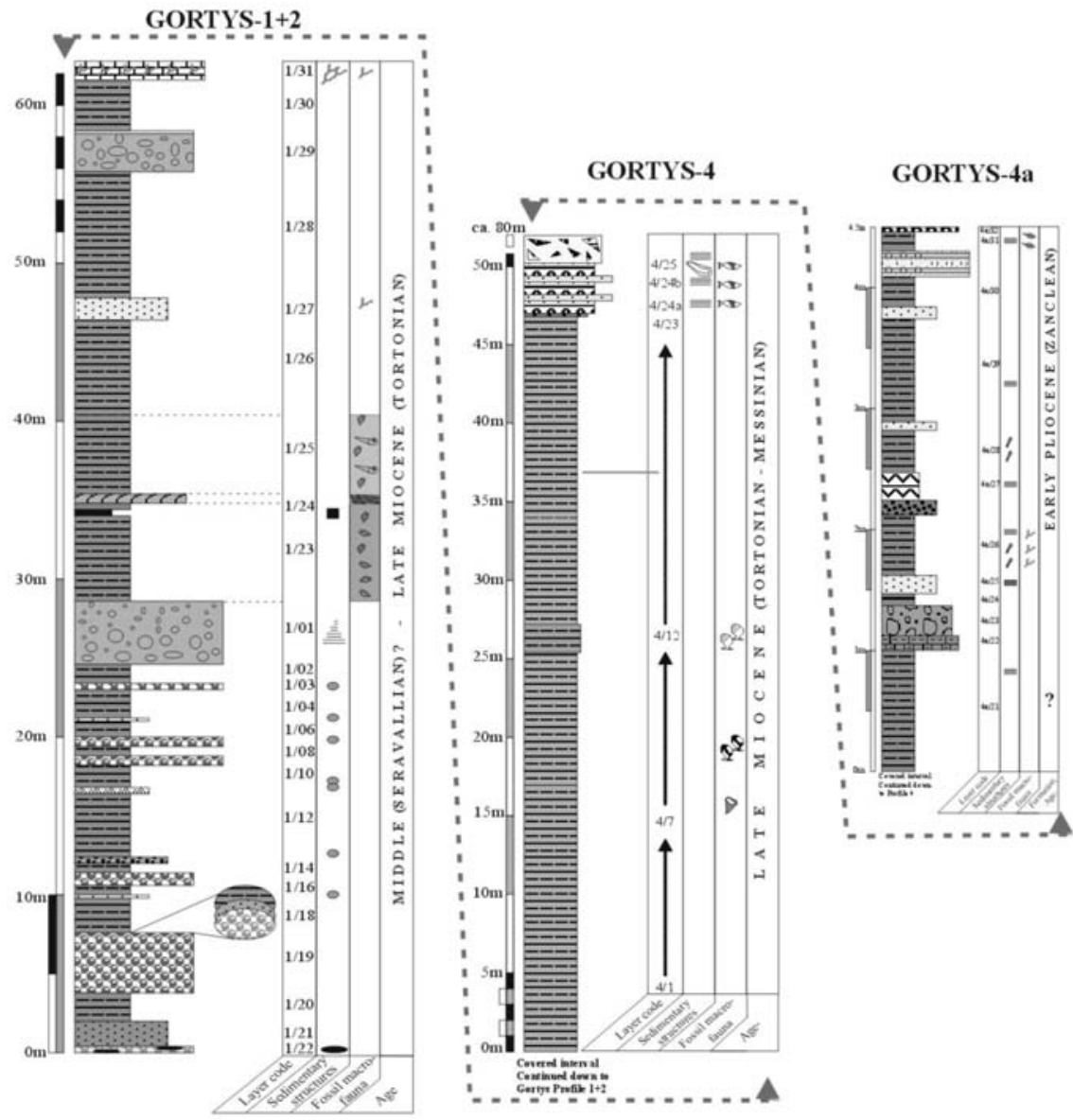

LE G E N D
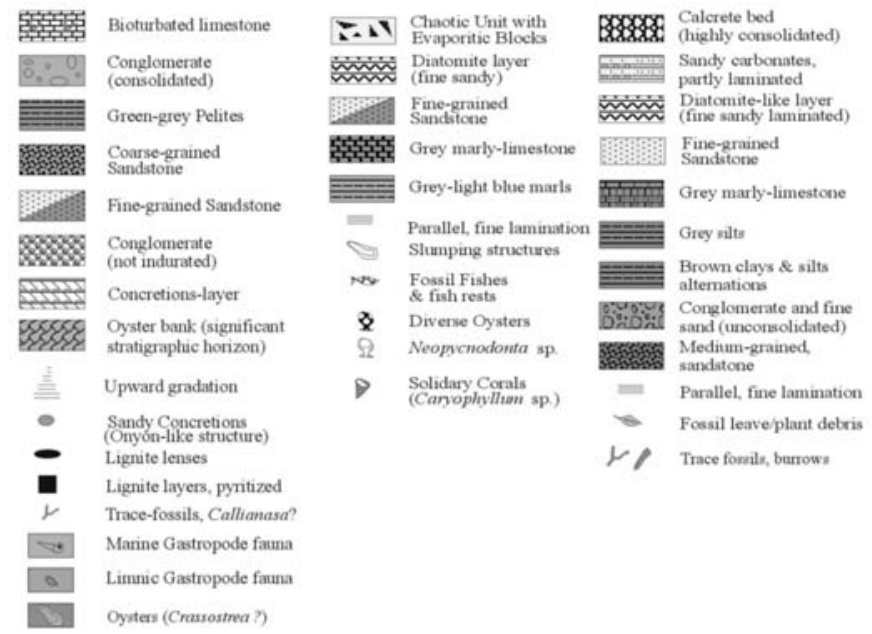

Fig. 2: Lithostratigraphy of the studied profiles; combined Gortys-1+2, Gortys-4 and Gortys-4a. 
Theodoxus sp. and Turritella tricincta. Further upwards, the mudrocks dominate almost to the top. Exceptionally, three distinct horizons are to be observed; a fine-grained sandstone bank by the level of $46.0 \mathrm{~m}$ (1.30m thick), a consolidated conglomerate by the level of $55.70 \mathrm{~m}$ ( $2.0 \mathrm{~m}$ thick) and a bioturbated limestone bearing traces of Callianasa sp. by the level of $62.0 \mathrm{~m}$, which closes the succession to the top.

\subsubsection{Profile Gortys-4}

A covered part of section exists between Gortys-1+2 and Gortys-4 Profiles. It seems that full-marine sedimentation (facies c) was developed again by the base of Gortys-4 Profile, mostly represented by grey to light blue marls of $48.0 \mathrm{~m}$ in thickness. Fossil solidary corals (like Caryophyllum sp.), rich levels in Neopycnodonta sp. and some levels with diverse Oysters macroscopically prove this facies (Fig. 2). By the top of the profile the lithology shifts to sands and finely to laminated sandy Diatomites. Small fossil fishes $(1-5 \mathrm{~cm})$ and fish-bone-rests are also observed. The profile closes at the top with a chaotic unit of ca. $28.0 \mathrm{~m}$, where evaporitic blocks of various sizes are incorporated (facies d, Messinian Salinity Crisis, MSC).

\subsubsection{Profile Gortys-4a}

Profile Gortys-4a measures $4.5 \mathrm{~m}$ in thickness and it is situated ca. $150 \mathrm{~m}$ to the west, over the main profile Gortys-4. It was sampled in order to complete the sedimentary record of the North Gortys subbasin area. It mainly consists of brown laminated silts and sands in alternation, bearing frequently plant debris and closes at the top with sandy carbonates and a calcrete bed (Fig. 2). A rich calcareous nannofossil flora gave evidence for the marine character of deposition (facies e).

\subsection{Biostratigraphy}

\subsubsection{Profile Gortys-4}

\section{Calcareous nannofossils}

Sixteen samples (s.1 to s.25) were biostratigraphically investigated from profile Gortys-4 (Table 1). The calcareous nannofossils assemblage recovered is very rich, well diversified and it is composed of at least 51 different species in total. In general preservation of fossil nannoplankton is very well to moderate. Secondary calcite overgrowth of several discoasterids is not the rule.

Ceratolithus cf. primus, although rare, is present from the basal sample (s.1). This is also apparent for Discoaster berggrenii/Discoaster quinqueramus intergrade. D. berggrenii FO (First occurrence) marks the base of CN9 Zone (Discoaster quinqueramus, Tab. 1) i.e. the base of CN9a subzone of Okada \& Bukry (1980). Since both taxa occur at the base of Gortys-4 profile and considering that the Amaurolithus primus FO defines the base of CN9b (Okada \& Bukry, 1980), it is obvious an assignment of the basal samples association to the CN9b subzone (co. Frydas \& Bellas, 2009). In the absence of A. delicatus, this is partly equivalent with the upper part of the NN11a subzone of Martini \& Müller (1986). Additionally, occurrences although rare of Helicosphaera stalis are in good agreement with this placement, which belongs to the A. primus Zone of Theodoridis (1984). Subsequently, samples association 1 to 18 is placed within the CN9b subzone of upper Tortonian age (Late Miocene). The LO (Lowest Occurrence) datum of A. primus (=LO of Amaurolithus spp.) was laid down to 7.424 Ma (Raffi et al., 2006; Tab. 3) and it was given an A (first) degree of reliability. Consequently, the Tortonian/Messinian boundary was also dated at 7.424 Ma for the Eastern Mediterranean, although generally it is dated at 7.246 Ma (Lourens et al., 2004). 
Table 1. Calcareous nannofossil biostratigraphy of the Late Miocene profile Gortys-4. FoV= One Field of View in the light microscope (LM), under a magnification of 768x.

\begin{tabular}{|c|c|c|c|c|c|c|c|c|c|c|c|c|c|c|c|c|c|}
\hline \multicolumn{17}{|c|}{ Profile Gortys-4, Messara Graben, south-central Crete } & $\rightarrow$ topwards \\
\hline \multicolumn{17}{|c|}{ Discoaster quinqueramus Zone (NN11, CN9) } & Biozone (Codation) \\
\hline \multicolumn{17}{|c|}{ LATE MIOCENE (TORTONIAN) $\| \rightarrow$ MESSINIAN } & Series, Stage \\
\hline 1 & 2 & 4 & 6 & 8 & 10 & 12 & 1 & & 16 & 18 & 19 & 20 & 22 & 23 & 24 & 25 & Studied samples $\mathrm{Nr}$ \\
\hline \multicolumn{17}{|c|}{$\begin{array}{c}+=\text { Present, } \mathrm{R}=\text { Rare }(1-4 / 50 \mathrm{FoV}), \mathrm{R} / \mathrm{F}=<1 / \mathrm{FoV}, \mathrm{F}=\mathrm{Few}(1-2 / \mathrm{FoV}), \mathrm{F} / \mathrm{C}=3-9 / \mathrm{FoV}, \mathrm{C}= \\
\text { Common }(10-20 / \mathrm{FoV}), \mathrm{A}=\text { Abundant }(21-50 / \mathrm{FoV}), \mathrm{VA}=\text { Very Abundant }(>51 / \mathrm{FoV})\end{array}$} & Calcareous nannofossils \\
\hline & & & & & & + & & + & + & & & $\mathrm{R}$ & $\mathrm{R}$ & & & & Nicklithus (A.) amplificus \\
\hline & & & & & & & & & & & $\mathrm{R}$ & $\mathrm{R}$ & & & & & A. delicatus \\
\hline \multirow[t]{2}{*}{$\mathrm{R}$} & $\mathrm{C}$ & $\mathrm{C}$ & $\mathrm{R}$ & + & $\mathrm{R}$ & $\mathrm{R} / \mathrm{F}$ & $\mathrm{R}$ & $\mathrm{R}$ & $\mathrm{R}$ & $\mathrm{R}$ & $\mathrm{R}$ & $\mathrm{R}$ & $\mathrm{R}$ & + & + & $\mathrm{R}$ & Calcidiscus leptoporus \\
\hline & $\mathrm{F}$ & $\mathrm{F}$ & $\mathrm{R}$ & $\mathrm{R}$ & $\mathrm{F} / \mathrm{C}$ & $\mathrm{F}$ & $\mathrm{F}$ & $\mathrm{F} /$ & C & $\mathrm{F}$ & $\mathrm{F}$ & $\mathrm{F}$ & $\mathrm{F}$ & $\mathrm{C}$ & $\mathrm{F} / \mathrm{C}$ & $\mathrm{F} / \mathrm{C}$ & Ca. macintyrei \\
\hline \multirow[t]{3}{*}{+} & $\mathrm{R}$ & + & & & $\mathrm{R}$ & & & + & + & + & + & & $\mathrm{R}$ & $\mathrm{R}$ & $\mathrm{R}$ & + & Ceratolithus cf.primus (birefr.) \\
\hline & & & & & & & & & & & & & & & & $\mathrm{R}$ & C.rugosus \\
\hline & & & & & & & & $\mathrm{R}$ & $\mathrm{R}$ & & & $\mathrm{R}$ & & & & & C.tricorniculatus \\
\hline \multirow[t]{2}{*}{$\mathrm{R}$} & $\mathrm{R}$ & $\mathrm{F}$ & $\mathrm{R}$ & $\mathrm{R} / \mathrm{F}$ & $\mathrm{C}$ & $\mathrm{C}$ & $\mathrm{F}$ & $\mathrm{R}$ & $\mathrm{R}$ & $\mathrm{R} / \mathrm{F}$ & $\mathrm{R} / \mathrm{F}$ & $\mathrm{R}$ & $\mathrm{R} / \mathrm{F}$ & $\mathrm{R} / \mathrm{F}$ & + & + & Coccolithus pelagicus \\
\hline & & & & & & $\mathrm{R}$ & & + & + & & $\mathrm{R}$ & $\mathrm{R} / \mathrm{F}$ & + & $\mathrm{R}$ & & & Cryptococcolithus takay. \\
\hline \multirow[t]{2}{*}{$\mathrm{R}$} & $\mathrm{R}$ & $\mathrm{F}$ & $\mathrm{F} / \mathrm{C}$ & $\mathrm{F} / \mathrm{C}$ & $\mathrm{C}$ & $\mathrm{C}$ & $\mathrm{F}$ & $\mathrm{F}$ & F & $\mathrm{R} / \mathrm{F}$ & $\mathrm{F}$ & $\mathrm{R}$ & $\mathrm{R}$ & $\mathrm{R} / \mathrm{F}$ & $\mathrm{R}$ & $\mathrm{R} / \mathrm{F}$ & Dictyococcites antarct. \\
\hline & $\mathrm{R} / \mathrm{F}$ & $\mathrm{R}$ & $\mathrm{R}$ & & $\mathrm{C}$ & & A & $\mathrm{V}$ & A & VA & $\mathrm{A}$ & $\mathrm{C}$ & $\mathrm{C} / \mathrm{A}$ & VA & $\mathrm{C}$ & $\mathrm{C} / \mathrm{A}$ & Dic.productus \\
\hline+ & + & $\mathrm{R}$ & & & & & & + & + & + & & & $\mathrm{R}$ & & + & & Discoaster adamanteus \\
\hline $\mathrm{R}$ & + & & $\mathrm{R}$ & & $\mathrm{R} / \mathrm{F}$ & & $\mathrm{R}$ & $\mathrm{F}$ & F & + & $\mathrm{F}$ & $\mathrm{F}$ & $\mathrm{R}$ & $\mathrm{R}$ & $\mathrm{R}$ & + & D. berggrenii-quinquer. \\
\hline \multirow[t]{3}{*}{$\mathrm{R}$} & + & & + & & & & & $\mathrm{R}$ & $\mathrm{R}$ & + & $\mathrm{R}$ & $\mathrm{F}$ & + & & & & D. brouweri \\
\hline & + & & & & + & & + & + & + & $\mathrm{R}$ & $\mathrm{R}$ & + & $\mathrm{R} / \mathrm{F}$ & $\mathrm{R}$ & & & D. challengeri \\
\hline & & & & & & & $\mathrm{R}$ & $t$ & + & + & & & & $\mathrm{R}$ & & & D.pansus \\
\hline \multirow[t]{3}{*}{$\mathrm{R}$} & + & & $\mathrm{R}$ & & $\mathrm{R} / \mathrm{F}$ & + & & $\mathrm{R}$ & $\mathrm{R}$ & $\mathrm{R}$ & $\mathrm{R}$ & $\mathrm{F}$ & $\mathrm{R} / \mathrm{F}$ & + & $\mathrm{R}$ & & D.pentaradiatus \\
\hline & & & & & & & + & & & & + & & & & & & D.prepentaradiatus \\
\hline & $\mathrm{R}$ & & & & & & & $\mathrm{R}$ & $\mathrm{R}$ & $\mathrm{R}$ & + & $\mathrm{R}$ & $\mathrm{R}$ & $\mathrm{R}$ & & & D. variabilis \\
\hline $\mathrm{R} / \mathrm{F}$ & $\mathrm{F}$ & $\mathrm{F}$ & $\mathrm{R}$ & $\mathrm{R}$ & $\mathrm{C}$ & $\mathrm{C}$ & $\mathrm{C}$ & $\mathrm{R}$ & $\mathrm{R}$ & $\mathrm{C}$ & $\mathrm{F} / \mathrm{C}$ & $\mathrm{R} / \mathrm{H}$ & $\mathrm{C}$ & $\mathrm{F} / \mathrm{C}$ & $\mathrm{F}$ & $\mathrm{R}$ & Discoaster sp.(6-arms) \\
\hline $\mathrm{R}$ & $\mathrm{R}$ & + & + & & & & & & & $\mathrm{R}$ & $\mathrm{R}$ & & + & & & & Discoasphaera tubifera \\
\hline A & A & $\mathrm{C}$ & $\mathrm{C}$ & $\mathrm{C}$ & $\mathrm{C}$ & A & $\mathrm{C}$ & C & $\mathrm{C}$ & $\mathrm{C}$ & $\mathrm{C} / \mathrm{A}$ & $\mathrm{C}$ & $\mathrm{A}$ & $\mathrm{C}$ & $\mathrm{C}$ & $\mathrm{C}$ & Geminilithella jafari \\
\hline $\mathrm{R}$ & $\mathrm{F}$ & $\mathrm{F}$ & $\mathrm{F}$ & $\mathrm{F}$ & $\mathrm{R} / \mathrm{F}$ & $\mathrm{F}$ & $\mathrm{R} / \mathrm{l}$ & $\mathrm{R}$ & $/ F$ & $\mathrm{~F}$ & $\mathrm{~F}$ & $\mathrm{~F}$ & $\mathrm{~F}$ & $\mathrm{~F}$ & $\mathrm{R} / \mathrm{F}$ & $\mathrm{R}$ & G. rotula \\
\hline+ & & & & & $\mathrm{R}$ & & & & & & $\mathrm{R}$ & & + & & & & Hayaster perplexus \\
\hline $\mathrm{F}$ & $\mathrm{F} / \mathrm{C}$ & $\mathrm{C}$ & $\mathrm{C}$ & $\mathrm{F} / \mathrm{C}$ & $\mathrm{C}$ & $\mathrm{C}$ & $\mathrm{C}$ & C & C & $\mathrm{C}$ & $\mathrm{C}$ & $\mathrm{F} / \mathrm{C}$ & $\mathrm{C}$ & $\mathrm{C}$ & $\mathrm{F} / \mathrm{C}$ & $\mathrm{C}$ & Helicosphaera carteri \\
\hline \multirow[t]{2}{*}{$\mathrm{R}$} & $\mathrm{R}$ & $\mathrm{R}$ & + & + & $\mathrm{R}$ & + & & + & + & + & & + & $\mathrm{R}$ & & & & H. intermedia-euphratis \\
\hline & & & & & $\mathrm{R}$ & & & & & & & & & & & & H.orientalis \\
\hline $\mathrm{R}$ & $\mathrm{R}$ & & & & & + & + & + & + & & & + & $\mathrm{R}$ & $\mathrm{R}$ & & & H.pacifica \\
\hline \multirow[t]{2}{*}{+} & + & $\mathrm{R}$ & $\mathrm{R}$ & $\mathrm{R}$ & $\mathrm{R}$ & $\mathrm{R}$ & + & + & + & + & & + & & & & & H. stalis stalis H. st.ovata \\
\hline & & & & & & + & & & & & & & & + & & & Lithostromation perdurum \\
\hline \multirow[t]{2}{*}{$\mathrm{R}$} & $\mathrm{R}$ & $\mathrm{R} / \mathrm{F}$ & $\mathrm{R}$ & $\mathrm{R}$ & $\mathrm{R} / \mathrm{F}$ & $\mathrm{R}$ & $\mathrm{R}$ & $\mathrm{R}$ & $\mathrm{R}$ & $\mathrm{R}$ & $\mathrm{R}$ & $\mathrm{R}$ & $\mathrm{R} / \mathrm{F}$ & $\mathrm{R} / \mathrm{F}$ & $\mathrm{R}$ & + & Pontosphaera spp. \\
\hline & & & & & & & + & & & & & + & & & & & Reticulofenestra minutula \\
\hline \multirow[t]{2}{*}{+} & & & $\mathrm{R}$ & & & $\mathrm{R} / \mathrm{F}$ & $\mathrm{R} / \mathrm{l}$ & & & $\mathrm{R}$ & + & & $\mathrm{R} / \mathrm{F}$ & $\mathrm{R} / \mathrm{F}$ & + & & R.pseudoumbilica $(>7 \mu m)$ \\
\hline & & & & & & & & & & & $\mathrm{R}$ & $\mathrm{R}$ & $\mathrm{R} / \mathrm{F}$ & $\mathrm{R} / \mathrm{F}$ & & & R.rotaria \\
\hline $\mathrm{R}$ & $\mathrm{F}$ & $\mathrm{F}$ & $\mathrm{R}$ & $\mathrm{R}$ & $\mathrm{F}$ & $\mathrm{F}$ & $\mathrm{R} / \mathrm{l}$ & $\mathrm{R}$ & R & $\mathrm{R} / \mathrm{F}$ & $\mathrm{R} / \mathrm{F}$ & $\mathrm{R} / \mathrm{F}$ & $\mathrm{F}$ & $\mathrm{R} / \mathrm{F}$ & $\mathrm{R} / \mathrm{F}$ & $\mathrm{F}$ & Rhabdosphaera spp. \\
\hline+ & + & & & & $\mathrm{F}$ & $\mathrm{R}$ & $\mathrm{R} / \mathrm{l}$ & + & + & $\mathrm{R} / \mathrm{F}$ & $\mathrm{R}$ & $\mathrm{R} / \mathrm{F}$ & $\mathrm{F}$ & $\mathrm{F}$ & & $\mathrm{R}$ & Scapholithus fossilis \\
\hline $\mathrm{R}$ & $\mathrm{R}$ & + & $\mathrm{R}$ & & + & $\mathrm{R}$ & + & + & + & + & + & + & $\mathrm{R}$ & $\mathrm{R}$ & + & & Scyphosphaera spp. \\
\hline $\mathrm{F} / \mathrm{C}$ & $\mathrm{F}$ & $\mathrm{C}$ & $\mathrm{R}$ & $\mathrm{F}$ & $\mathrm{F}$ & $\mathrm{R}$ & $\mathrm{F}$ & $\mathrm{F}$ & $F$ & $\mathrm{R} / \mathrm{F}$ & $\mathrm{F}$ & $\mathrm{F}$ & $\mathrm{F} / \mathrm{C}$ & $\mathrm{F} / \mathrm{C}$ & $\mathrm{C}$ & A & Sphenolithus abies \\
\hline $\mathrm{R}$ & & & & & & & & & & + & & & & + & & & Sph.verensis \\
\hline \multirow[t]{2}{*}{+} & $\mathrm{R}$ & $\mathrm{R} / \mathrm{F}$ & $\mathrm{R}$ & & $\mathrm{R}$ & $\mathrm{R}$ & & + & + & $\mathrm{R}$ & & & & & & + & Syracosphaera sp. \\
\hline & $\mathrm{R}$ & & & & & & + & & & & + & $\mathrm{R}$ & + & $\mathrm{R}$ & + & & Triquetrorhabdulus rug. \\
\hline
\end{tabular}


Moving upwards, an occurrence of A. delicatus is recorded at the level of s.19 together with the FO of Reticulofenestra rotaria. The same pattern was also observed in the Pissouri section in Cyprus (Morigi et al., 2007). Both species are considered indicative of slightly predate the Tortonian/ Messinian (T/M) stages boundary. Although the LO biohorizon of A. delicatus, considered not reliable for open oceanic correlations by Raffi et al. (2006), it is very useful for marginal Seas like the Mediterranean. This bioevent, indeed, is recognized as the closest event to the Globorotalia miotumida datum and subsequently a good approximation for the T/M boundary (Morigi et al., 2007 and references therein). Based on the appearance of the former species the calcareous nannofossil assemblage of s.19 and upwards can be placed in the NN11b subzone of Martini \& Müller (1986). Individuals of $D$. berggrenii/D. quinqueramus intergrade are consistently present along the studied section almost to the top.

The appearance and rapid extinction of Nicklithus (former Amaurolithus) amplificus bounds an interval within the CN9b subzone defined as CN9bB, with a C degree of reliability (Raffi \& Flores, 1995; Raffi et al., 2006). In our record, this stratigraphic interval is found between s.20 and s.22. Following Raffi \& Flores (1995) emended by Fornaciari (2000), it is therefore suggested an assignment of the s.19 assemblage (in the absence of $N$. amplificus) to the CN9bA subzone, while according to Martini \& Müller (1986) it already belongs to the NN11b subzone. The nannofossils association of s.23 and s.24 is placed to the next younger in age subzone CN9bC due to absence of $N$. (A.) amplificus (Raffi \& Flores, 1995 emend. by Fornaciari, 2000). However, $R$. rotaria is still present in s.23, making also possible an assignment of samples assemblage interval 19 to 23 to the homonymous Zone of Theodoridis (1984), which is partly equivalent with the NN11b subzone.

Ceratolithus rugosus occurrence only in the uppermost s.25 could place this assemblage in the CN10b subzone of Okada \& Bukry (1980). Fornaciari (2000) did not utilize this species due to its rarity and Raffi et al. (2006) suggested a very low degree of reliability (D) to this event (considering its Lowest Occurrence). Therefore this event appears to be unreliable.

Summarizing, the samples interval between 1 and 25 of the Gortys- 4 studied profile, is placed to the Late Miocene and specifically, the s. 1-18 to the Tortonian (CN9b, NN11a) and the s. 19-24 to the Messinian (CN9bA to CN9bC, NN11b), while s.25 could be a matter of debate (see below).

\section{Siliceous component of GORTYS-4}

Pennate diatom taxa like Grammatophora sp., Rhizosolenia sp. and Actiniscidians are included in the siliceous association of s.24b, but their preservation is rather moderate. The Silicoflagellate Distephanus speculum and centrate Diatoms like Coscinodiscus sp. are incorporated in the uppermost part of Gortys-4 (s.25), situated directly below the chaotic Evaporites. Additionally, Sponge spicules (s.25) like Oxeas, Triods etc. are common and present great variability.

Occurrence of Ds. speculum is biostratigraphically significant being indicative of the almost homonymous biozone Distephanus speculum speculum of the Late Miocene (Frydas, 1996). The recorded association can be correlated with a similar one from NW Crete (Messinian assemblage), Kastelli/Kissamou Neogene Basin (Keupp \& Bellas in collab. Frydas \& Bartholdy, 2000).

\subsubsection{Profile Gortys-4a (supplement to Gortys-4)}

Despite the relative reduced thickness of the studied profile, its stratigraphical importance is major, since it contributes to the completion of the Gortys subbasin evolution in course of Early Pliocene (postdate the MSC). Seven samples were biostratigraphically investigated. The calcareous nannofossils recov- 
ered are well diversified (41 identified species), but they occur in relatively low frequencies and rather inconsistently. In a biostratigraphic context, this is a very complicated profile. Following bioevents were identified along the studied profile moving from the base to the top (s.26b to s.32, Table 2):

Table 2. Calcareous nannofossil biostratigraphy of the early Pliocene profile Gortys-4a

\begin{tabular}{|c|c|c|c|c|c|c|c|}
\hline \multicolumn{8}{|c|}{$\begin{array}{l}\text { Profile Gortys-4a, Messara Graben, south-central Crete } \\
\end{array}$} \\
\hline \multicolumn{7}{|c|}{ (NN14/15-NN16, CN10-CN11a- ?b) } & Biozone (Codation) \\
\hline \multicolumn{7}{|c|}{ EARLY PLIOCENE (ZANCLEAN) } & Series, Stage \\
\hline 26b & $27 \mathbf{b}$ & $28 b$ & 29 & 30 & 31a & 32 & S Studied samples $\mathrm{Nr}$ \\
\hline \multicolumn{7}{|c|}{ Abbreviations like in previous Table $(+, \mathrm{R}, \mathrm{F}, \mathrm{C}, \mathrm{A})$} & Calcareous nannofossils \\
\hline & + & & & & & & Amaurolithus delicatus \\
\hline+ & & $\mathrm{R}$ & + & $\mathrm{R}$ & & & Amaurolithus sp. \\
\hline $\mathrm{R}$ & & & $\mathrm{C}$ & $\mathrm{C}$ & $\mathrm{R}$ & $\mathrm{C}$ & Calcidiscus leptoporus \\
\hline \multirow[t]{2}{*}{$\mathrm{F} / \mathrm{C}$} & $\mathrm{F}$ & $\mathrm{C}$ & & + & & & Ca. macintyrei \\
\hline & & & + & + & & $\mathrm{R}$ & Ceratolithus cf.primus \\
\hline+ & & + & + & & & & C. tricorniculatus \\
\hline+ & + & & $\mathrm{R}$ & $\mathrm{R}$ & & + & Coccolithus pelagicus \\
\hline $\mathrm{R}$ & & + & + & + & & & Dictyococcites antarcticus \\
\hline \multirow[t]{2}{*}{$\mathrm{C}$} & $\mathrm{F} / \mathrm{C}$ & $\mathrm{C}$ & $\mathrm{C}$ & $\mathrm{F}$ & $\mathrm{F}$ & $\mathrm{F}$ & Dic.productus \\
\hline & & & & $\mathrm{R}$ & & + & Discoaster asymmetricus \\
\hline+ & & & & & & & D. berggrenii-quinqueramus \\
\hline \multirow[t]{6}{*}{$\mathrm{R}$} & $\mathrm{F}$ & + & + & & & & D. brouweri \\
\hline & + & & $\mathrm{R}$ & + & & & D. challengeri \\
\hline & $\mathrm{R} / \mathrm{F}$ & & & & & & D. intercalaris \\
\hline & & & $\mathrm{R}$ & $\mathrm{F}$ & & & D. mendomobensis \\
\hline & & $\mathrm{R}$ & & & & & D.pansus \\
\hline & $\mathrm{R}$ & & $\mathrm{C}$ & $\mathrm{F} / \mathrm{C}$ & & + & D. pentaradiatus \\
\hline+ & $\mathrm{R}$ & & & + & & & D. surculus \\
\hline $\mathrm{R}$ & $\mathrm{F}$ & + & & + & & & D. variabilis \\
\hline $\mathrm{C}$ & $\mathrm{F}$ & $\mathrm{F}$ & $\mathrm{R} / \mathrm{F}$ & $\mathrm{R} / \mathrm{F}$ & & + & Discoaster sp.(6-arms) \\
\hline+ & & + & & & & + & Discoasphaera tubifera \\
\hline A & A & $\mathrm{F} / \mathrm{C}$ & $\mathrm{F}$ & & & $\mathrm{R}$ & Geminilithella jafari \\
\hline \multirow[t]{3}{*}{$\mathrm{F}$} & $\mathrm{F}$ & $\mathrm{F}$ & $\mathrm{F}$ & $\mathrm{F}$ & $\mathrm{C}$ & $\mathrm{C} / \mathrm{A}$ & G. rotula \\
\hline & & & & & $\mathrm{F}$ & $\mathrm{C} / \mathrm{A}$ & Geminilithella sp.(med.) \\
\hline & & & + & & & & Hayaster perplexus \\
\hline \multirow[t]{3}{*}{$\mathrm{C}$} & $\mathrm{C}$ & $\mathrm{C}$ & $\mathrm{F}$ & $\mathrm{F}$ & $\mathrm{F} / \mathrm{C}$ & $\mathrm{C}$ & Helicosphaera carteri \\
\hline & & & $\mathrm{R}$ & & & & H. intermedia-euphratis \\
\hline & $\mathrm{R}$ & & & $\mathrm{R}$ & & & Lithostromation perdur. \\
\hline+ & $\mathrm{R} / \mathrm{F}$ & $\mathrm{R}$ & + & & & $\mathrm{R}$ & Pontosphaera spp. \\
\hline+ & & & + & & & & Reticulofenestra pseudoumb. $\mu$ ) \\
\hline $\mathrm{F} / \mathrm{C}$ & $\mathrm{F} / \mathrm{C}$ & $\mathrm{F}$ & $\mathrm{F}$ & $\mathrm{R}$ & $\mathrm{R} / \mathrm{F}$ & $\mathrm{F}$ & Rhabdosphaera spp. \\
\hline \multirow[t]{2}{*}{$\mathrm{R}$} & + & & + & + & & + & Scapholithus fossilis \\
\hline & $\mathrm{R} / \mathrm{F}$ & + & + & $\mathrm{R}$ & + & $\mathrm{F}$ & Scyphosphaera spp. \\
\hline \multirow[t]{2}{*}{$\mathrm{C}$} & $\mathrm{C}$ & $\mathrm{C}$ & $\mathrm{C}$ & $\mathrm{C}$ & $\mathrm{F}$ & $\mathrm{F}$ & Sphenolithus abies \\
\hline & & & $\mathrm{R}$ & $\mathrm{F}$ & & & Sph.neoabies \\
\hline+ & $\mathrm{R} / \mathrm{F}$ & $\mathrm{F}$ & $\mathrm{F} / \mathrm{C}$ & $\mathrm{F}$ & & & Sph. verensis \\
\hline $\mathrm{R} / \mathrm{F}$ & $\mathrm{F}$ & $\mathrm{F}$ & $\mathrm{F}$ & $\mathrm{R}$ & & $\mathrm{R} / \mathrm{F}$ & Syracosphaera spp. \\
\hline+ & & & & & & & Triquetrorhabdulus rugosus \\
\hline
\end{tabular}


D. berggrenii/D. quinqueramus intergrade is absent, out of a simple presence in the basal s.26b. This excludes the nannofossils NN11 (CN9) Zone and in this context, the recorded association is indicative of a younger zone. Triquetrorhabdulus rugosus has also its only and Highest Occurrence (HO) in basal s.26b. This event marks the CN10a/CN10b subzones boundary (Okada \& Bukry, 1980) with a given astronomical age estimation of 5.279 Ma from ODP data (Lourens et al., 2004; Raffi et al., 2006).

Ceratolithus tricorniculatus with a HO at s.29 has been commonly utilized as to define various zonal boundaries like 1) the CN10/CN11 (Okada \& Bukry, 1980) and/or 2) the biostratigraphically equivalent MNN12/MNN13 in the Mediterranean (Rio et al., 1990; Fornaciari et al., 1996) and/or 3) the NN14/NN15 of Martini \& Müller (1986).

Amaurolithus sp. disappears higher at the level of s.30. Usually, the HO of Amaurolithus primus was used to define the CN10/CN11 zones boundary (Okada \& Bukry, 1980; Raffi et al., 2006). An age estimation of 4.50 Ma from ODP Leg 138 data is given for this event by Lourens et al. (2004).

Usually the extinction of sphenoliths (HO of Sphenolithus spp.) is used to define the early Pliocene (Zanclean)/mid Pliocene (Piacenzian) boundary (CN12aA/CN12aB subzones boundary) and it is approximated with an age of 3.7 Ma for the eastern Mediterranean (Lourens et al., 1996) or 3.65 Ma (Raffi et al., 2006: degree of bioevent reliability C). The HO of Reticulofenestra pseudoumbilica approximates this boundary as well (extinction at 3.839 Ma for E. Mediterranean in Raffi et al., 2006: zonal boundary $\mathrm{CN} 11 \mathrm{~b}-\mathrm{CN} 12 \mathrm{aA}$, degree of reliability A). In our record, the $\mathrm{HO}$ of $R$. pseudoumbilica (although very scarcely present) is found at s.29, while the sphenoliths distribution pattern shows consistent occurrence to the top of the section, pointing clear to a still Zanclean age of the uppermost Gortys-4a assemblage (CN11a to ?CN11b subzone).

Summarizing, the nannofossil association of the basal sample $26 \mathrm{~b}$ can be placed in the CN10a subzone due to the presence of T.rugosus. The next association (samples 27b to 29) belongs to the subzone CN10b. This is suggested by the presence of A. tricorniculatus, R. pseudoumbilica and Sph. abies, Sph. neoabies and Sph. verensis. Discoaster asymmetricus is found scarce and rare (s. 30 \& 32), while FCO (First Common Occurrence) of D. asymmetricus marks the CN11a/CN11b boundary (Okada \& Bukry, 1980; Rio et al., 1990; Fornaciari et al., 1996; degree of reliability B, with an age of 4.120 Ma in E. Mediterranean, Raffi et al., 2006). In the next samples (31a \& 32), the disappearance of A. tricorniculatus, Sph. neoabies and Sph. verensis, the reduce in frequency of Sph. abies, the very scarce occurrences of D. asymmetricus in conjunction with the bioevent of Discoaster pentaradiatus PE (introduced by Fornaciari, 2000) in the absence of Discoaster tamalis (FO in the CN11b subzone) and Pseudoemiliania lacunosa (FO within the CN11b), are all indicative of the subzones interval CN10c to CN11a.

Summarizing, all the available data indicate a lower Pliocene age (Zanclean) for the Gortys-4a profile and place its deposits (together with those of Kourtes) among the youngest in the Messara area.

\section{Concluding remarks}

In order to improve our knowledge of the late Cenozoic geological history of central Crete, we studied four Neogene outcrops north of Gortys ancient city ruins in the Messara plain (Gortys subbasin). Due to lithostratigraphical similarities, two of them (Gortys-1 and -2) which represent the older strata, were combined as one (Gortys-1+2) and are interpreted as fresh-water (fluvial) to lagoon deposits. The other two studied Profiles (Gortys-4 and -4a), which represent the depositional continuation of the previous, represent a marine development of the subbasin towards the top, interrupted 
by the MSC (recorded as a chaotic evaporites unit at the upper part of Gortys-4). For the latter two profiles was applied calcareous and siliceous nannofossils biostratigraphy.

A Late Miocene age is given to the deposits of Profile Gortys-4. The calcareous nannofossils assemblages characterize the Discoaster quinqueramus Zone (NN11, CN9) and specifically, the samples assemblage s.1 to s.18 (lower part of the profile) suggest an assignment to the CN9b (NN11a or Amaurolithus primus) subzones of Tortonian (sensu Okada \& Bukry, 1980; Martini \& Müller, 1986; Theodoridis, 1984), while samples assemblages s.19 to s.24 assigned to the CN9bA to CN9bC [sensu Raffi \& Flores (1995) emend. by Fornaciari (2000)] (or NN11b or Reticulofenestra rotaria) subzones of lower Messinian (Martini \& Müller, 1986; Theodoridis, 1984). Key species include biohorizons and correspondent reliability degrees (Raffi et al., 2006) of A. primus, A. delicatus, D. berggrenii/D. quinqueramus, $H$. stalis, $R$. rotaria and $N$. amplificus.

Additionally, occurrence of the silicoflagellate species Distephanus speculum clearly points out to a Late Miocene age for the uppermost sample assemblage of Profile Gortys-4 (s.25). This fact together with development of the chaotic evaporites above s. 25, proves the Late Miocene age of the section sediments. Large similarities were detected in litho- and bio-stratigraphy context between Gortys-4 and Pissouri section in Cyprus (co. Morigi et al., 2007).

Considering the calcareous nannofossil assemblage of profile Gortys-4a, last record of T. rugosus (HO) is found in basal s.26b. This event marks the CN10a/CN10b subzones boundary (Okada \& Bukry, 1980) with a given astronomical age estimation of 5.279 Ma (Lourens et al., 2004; Raffi et al., 2006). Since D. asymmetricus FCO is estimated with an age of $4.120 \mathrm{Ma}$ in E. Mediterranean and this event has not been detected in the studied samples of profile Gortys-4a, it means that the uppermost layers of the profile are surely younger in age than this estimation. Subsequently, the calcareous nannofossil assemblage of Gortys-4a characterizes the uppermost CN10a to CN11a subzones (Zanclean, early Pliocene) and covers an interval of approximately 1.159 my of deposition. Key species include absence of D. berggrenii/D. quinqueramus and biohorizons of T.rugosus, A. delicatus, D. asymmetricus, Sphenolithus spp.

Concluding, the Gortys subbasin development commenced with a thick succession of fluvial deposits (Gortys-1+2) possibly in the course of Seravallian to lower Tortonian (based on the fact that they underlie and subsequently predate the Tortonian age marine strata of Gortys-4), then sedimentation turned to lagoonal and after an azoic silty interval started the pure marine transgression in the subbasin during upper Tortonian, while deepening of it continued in the lower Messinian (Gortys4). Evaporites predominantly of chaotic structure close this succession to the top, pointing to the well known desiccation (MSC) of the Mediterranean (top of Gortys-4). After a covered interval, strata of profile Gortys-4a record a renewal of transgression (lower Pliocene) in the course of Zanclean. It is suggested that the Gortys subbasin area should have been uplifted in Piacenzian (middle Pliocene) and remain exposed since then.

\section{Acknowledgments}

S.B. would like to thank the D.F.G. (German Research Foundation) for financial support during the I.C.D.P. (International Continental Drilling Project) Ke322/26-1. Preparation and study of samples was made possible at the Free University of Berlin (Institute of Geosciences).

\section{References}

Angelier, J., Lyberis, N., Le Pichon, X., Barrier, E., Huchon, Ph., 1982. The tectonic development of the 
Hellenic arc and the sea of Crete: a synthesis, Tectonophysics, 86, 159-196.

Bellas, S. \& Keupp, H., 2004, Die geologische Entwicklung des Beckens von Messara (Kreta) im Neogen: das Teil-Becken von NE Mires als Fallstudie, Deutch-Griechische Forschung 2003, Tagungsband 1 (Geo- und Umweltwissenschaften), 1, 80-88, Berlin, Wissenschaftlicher Verlag.

Berggren, W.A., Kent, D.V., Swisher, C.C. III and Aubry, M.-P., 1995. A Revised Cenozoic Geochronology and Chrono-stratigraphy. In W.A. Berggren, D.V. Kent, M.-P. Aubry, and J. Hardenbol (eds), Geochronology, Time Scales and Global Stratigraphic Correlation, SEPM (Society for Sedimentary Geology) Spec. Publ., 54, 129-212.

Brachert, T.C., Reuther, M., Felis, T., Kroeger, K.F., Lohmann, G., Micheels, A. \& Fassoulas, C., 2006. Porites corals from Crete (Greece) open a window into Late Miocene (10Ma) seasonal and interannual climate variability, Earth and Planetary Science Letters, 245, 81-94.

Christodoulou, G., 1963. Geologische und mikropalaeontologische Untersuchungen im Neogen der Insel Kreta, Habilitation, Athens, University of Athens, 157pp.

Delrieu, B., Rouchy, J.-M. \& Foucault, A., 1993. La surface d'érosion finimessinienne en Crète centrale (Grèce) et sur le pourtour mediterranéen: rapports avec la crise de salinité mèditerranéenne, $C . R$. Acad. Sci. Paris, 316 (Ser. II), 527-533.

Delrieu, B., Saint Martin, J.-P. \& Merle, D., 1991. Un modèle d'évolution tectonosédimentaire dans le domaine sud-égéen au Miocène supérieur: l'accident d'Aghia Varvara (Crète centrale, Grèce), C.R. Acad. Sci. Paris, 313 (Ser. II), 1043-1049.

Demske, D., Keupp, H. and Bellas, S. (in prep.). Stratigraphy, palynology and paleogeography of Miocene deposits from Messara (Gortys), Crete, Greece.

Drinia, H., Koskeridou, E. \& Antonarakou, A., 2005. Late Pliocene Benthic Foraminifera and Molluscs from the Atsipades section, Central Crete; Paleoecological distribution and use in Paleoenvironmental assessment, Geobios, 38, 315-324.

Driever, B.W.M., 1988. Calcareous nannofossil biostratigraphy and paleoenvironmental interpretation of the Mediterranean Pliocene, Utrecht Micropal. Bull., 36, 1-245.

Fassoulas, C., 2001: The tectonic development of a Neogene basin at the leading edge of the active European margin: the Heraklion basin, Crete, Greece, Journal of Geodynamics, 31, 49-70.

Flores, J.A., Sierro, F.J. \& Glacon, G., 1992. Calcareous plankton analysis in the pre-evaporitic sediments of the ODP Site 654 (Tyrrhenian Sea, Western Mediterranean), Micropaleontology, 38(3), 279-288.

Fornaciari, E., 2000. Calcareous nannofossils biostratigraphy of the California margin. In Lyle, M., Koizumi, I., Richter, C. \& Moore, T.C.Jr. (eds), Proc. ODP, Sci. Res., 167: 3-40; Texas, A \& M University.

Fornaciari, Di Stefano, A., Rio, D. \& Negri, A., 1996. Middle Miocene quantitative calcareous nannofossil biostratigraphy in the Mediterranean Region, Micropaleontology, 42(1), 37-63.

Frydas, D., 1985. Siliceous phytoplankton from a diatomite near Heraklion, Crete, Greece, Newsletter Stratigr., 14, 142-157.

Frydas, D., 1987. Silicoflagellaten aus dem Messinium von Kreta, Griechenland, Z. dt. Geol. Ges., 138, $53-75$.

Frydas, D., 1990. Stratigraphie des diatomites du Plaisancien de la Crète centrale (Grèce) a l'aide des Silicoflagellés et des nannofossiles calcaires, Rev. Micropaléont., 33(2), 93-114.

Frydas, D., 1998. Upper Pliocene diatoms and silicoflagellates from section Fortessa, central Crete, Greece, Bull. Geol. Soc. Greece, 32(2), 93-100.

Frydas, D., 1999. Paleoecology, stratigraphy and taxonomy of the Pliocene marine Diatomites from central crete (Greece), Rev. Micropaléont., 42(4), 269-300, Paris.

Frydas, D., 2004. Calcareous and siliceous phytoplankton stratigraphy of Neogene marine sediments in 
central Crete (Greece), Rev. Micropaléont., 47, 87-102.

Frydas, D., 2006. Siliceous phytoplankton biostratigraphy of the pre-evaporite Messinian diatomites in Gavdos Island, Greece, Rev. Micropaléont., 49, 86-96.

Frydas, D. and Bellas, S., 2009. Calcareous phytoplankton stratigraphy of Neogene marine sediments eastern of Heraklion, Crete, Greece, Berl. Palaobiol. Abh., 10, 151-170.

Frydas, D. \& Keupp, H., 1996. Biostratigraphical results in Neogene deposits of NW Crete, Greece, based on calcareous nannofossils, Berliner geowiss. Abh., E 18, 169-189; Berlin.

Frydas, D., Keupp, H. \& Bellas, S., 2008. Stratigraphical investigations based on calcareous and siliceous phytoplankton assemblages from the Upper Cenozoic deposits of Messara Basin, Crete, Greece, Z. dt. Ges. Geowiss., 159/3, 415-437.

Frydas, D., Rouchy, J.-M. \& Delrieu, B., 1994. Paleoecology and Stratigraphy from siliceous phtytoplankton of Messinian age at central Crete, Greece, Bull. Geol. Soc. Greece, 30(2), 345-354, [In Greek with English abstract].

IGME, 1984. Geological map of Crete. Sheet, “Timbakion”.- Edition of the Institute of Geology and Mineral Exploration (IGME); Athens.

Jackson, J., 1994. Active tectonics of the Aegean Region, Annu. Rev. Earth Planet. Sci., 22, 239-271.

Jarvis, A., Reuther, H., Nelson, A., Guevara, E., 2008. Hole-filled SRTM for the globe, ver. 4. http://SRTM.csi.cgiar.org.

Jonkers, H. A., 1984. Pliocene benthonic foraminifera from homogeneous and laminated marls in Crete, Utrecht Micropal. Bull., 31, 1-179.

Keupp, H., Bellas, S., Frydas, D. \& Kohring, R., 1994. Aghia Irini, ein Neogenprofil auf der Halbinsel Gramvoússa/NW-Kreta, Berliner geowiss.Abh., E13, 469-481, Berlin.

Keupp, H. \& Bellas, S. in collab. Frydas, D. \& Bartholdy, J., 2000. Neogene development of the sedimentary basins of NW Crete island, Chania Prefecture, South Aegean Island Arc System (Greece), Berliner geowiss. Abh., E 34, 3-117.

Koskeridou, E., 2006. Pliocene Molluscs taxonomic diversity as a tool for the climatic-oceanographic reconstruction and stratigraphy. Two examples from the eastern Mediterranean, Bull. Soc. Geol. Greece, XXIX/I, 80-86.

LePichon, X., 1982. Landlocked oceanic basins And continental collision: the eastern Mediterranean as a case example. In K. Hsü (ed), Mountain Building Processes. 201-211, London, Academic Press.

Lourens, L.J., Hilgen, F.J., Zachariasse, W.J., Van Hoof, A.A.M., Antonarakou, A. \& Vergnaud-Grazzini, C., 1996. Evaluation of the Pliocene to early Pleistocene astronomical time scale, Paleoceanography, $11,391-413$.

Lourens, L., Hilgen, F.J., Shackleton, N.J., Laskar, J., Wilson, D., 2004. The Neogene Period. In F.M. Gradstein, J.G. Ogg, A.G. Smith (eds), A Geological Time Scale 2004, 409-440, Cambridge, Cambridge University Press.

Makris, J., 1978. The crust and upper mantle of the Aegean region from deep seismic soundings, Tectonophysics, 46, 269-284.

Martini, E., 1971. Standard Tertiary and Quaternary nannoplankton zonation. In A. Farinacci (ed), Proc. II ${ }^{\text {nd }}$ Planktonic Conference, Roma (1970), II, 739-777, Tecnoscienza.

Martini, E. \& Müller, C., 1986. Current Tertiary and Quaternary calcareous nannoplankton stratigraphy and correlations, Newsl. Stratigr., 16 (2), 99-112.

Mertz-Kraus, R., Brachert T.C., Reuter, M., Galer, S.J.G., Fassoulas, C., Iliopoulos, G., 2009. Late Miocene sea surface salinity increase in the Eastern Mediterranean inferred from coral $\delta^{18} \mathrm{O}$ variation, Chemical Geology, (doi:10.1016/j.chemgeo.2009.01.010). 
Meulenkamp, J.E., in coll. with Dermitzakis, M., Georgiadou-Dikeoulia, E., Jonkers, H.A. and Boeger, H., 1979. Field guide to the Neogene of Crete, Publ. Dept. Geol. Pal. Univ. Athens, Ser.A, 32, 1-15.

Meulenkamp, J.E., van der Zwaan, G.J., van Wamel, W.A., 1994. On Late Miocene to Recent vertical motions in the Cretan segment of the Hellenic arc, Tectonophysics, 234, 53-72.

Morigi, C., Negri, A., Giunta, S., Kouwenhoven, T., Krijgsman, W., Blanc-Valleron, M.-M., Orszag-Sperber, F., Rouchy, J.-M., 2007. Integrated quantitative biostratigraphy of the latest Tortonian-early Messinian Pissouri section (Cyprus): An evaluation of calcareous plankton events, Geobios, 40, 267-279.

Negri, A. \& Villa, G., 2000. Calcareous nannofossil biostratigraphy, biochronology and paleoecology at the Tortonian/Messinian boundary of the Faneromeni section (Crete), Paleogeography, Paleoclimatology, Paleoecology, 156, 195-209.

Okada, H. \& Bukry, D., 1980. Supplementary modification and introduction of code numbers to the lowlatitude coccolith biostratigraphic zonation (BUKRY, 1973, 1975), Mar. Micropaleontol., 5 (3), 321-325.

Papanikolaou, D. \& Nomikou, P.V., 1998. Neotectonic blocks and planation surfaces in Iraklion basin, Crete, Greece, Bull. Geol. Soc. Greece, 32 (1), 231-239.

Papanikolaou, D., Vassilakis, E., 2009. Thrust faults and extensional detachments faults in Cretan tectonostratigraphy: Implications for Middle Miocene extension, Tectonophysics, doi: 10.1016/j.tecto.2009.06.024

Perch-Nielsen, K., 1985. Cenozoic calcareous nannofossils. In H.M. Bolli, J.B. Saunders, and K. PerchNielsen (eds), Plankton Stratigraphy, 427-554, London, Cambridge Univ. Press.

Peterek, A. \& Schwarze, J., 2004. Architecture and Late Pliocene to recent evolution of outer-arc basins of the Hellenic subduction zone (south-central Crete, Greece), J. Geodynamics, 38, 19-55.

Psarianos, P., 1961. Tyrrhenian deposits of Crete Island, Ann. Geol. Pays Hell., 12, 12-17 (in gr.).

Raffi, I. and Flores, 1995. Pleistocene through Miocene calcareous nannofossils from eastern Equatorial Pacific Ocean. In N.G. Pisias, L.A. Mayer, T.R. Janecek, A. Palmer-Julson, and T.H. van Andel, (eds), Proc. O.D.P., Sci.Results, 138, 233-286, College Station, TX.

Raffi, I., Mozzato, C., Fornaciari, E., Hilgen, F.J. and Rio, D., 2003. Late Miocene calcareous nannofossil biostratigraphy and astrobiochronology for the Mediterranean region, Micropaleontology, 49(1), 1-26.

Raffi, I., Backman, J., Fornaciari, E., Pälike, H., Rio, D., Lourens, L. Hilgen, F.J., 2006. A review of calcareous nannofossil astrobiochronology encompassing the past 25 million years, Quaternary Science Reviews, 25, 3113-3137.

Reuther, M., Brachert, T. \& Kroeger, K.F., 2006. Shallow-marine carbonates of the tropical-temperate transition zone: effects of hinterland climate and basin physiography (late Miocene, Crete, Greece), Geol. Soc. London, Spec. Publ., 255, 157-178.

Rio, D., Raffi, I. \& Villa, G., 1990. Pliocene-Pleistocene calcareous nannofossil distribution patterns in the western Mediterranean. In K.A. Kastens, J. Mascle, et al., (eds), Proc. O.D.P. Sci.Results, 107, 513-533, College Station, TX.

Rio, D., Cita, M.B., Iaccarino, S., Gelati, R. \& Gnaccolini, M., 1997. Langhian, Serravallian, and Tortonian historical stratotypes. In A. Montanari, G.S. Odin, and R. Coccioni (eds), Miocene Stratigraphy: An Integrated Approach 57-87, Amsterdam, Elsevier.

Schackleton, N.J., Baldauf, J.A., Flores, J.-A., Iwai, M., Moore, T.C., jr., Raffi, I. \& Vincent, E., 1995. Biostratigraphic summary for Leg 138. In N.G. Pisias, et al., (eds), Proc. ODP, Sci. Results, 138, 517-533, College Station, TX.

Sprovieri, R., Di Stefano, E. \& Sprovieri, M., 1996. High resolution chronology or late Miocene Mediterranean stratigraphic events, Riv. Ital. Paleontol. Strat., 102(1), 77-104.

Ten Veen, J.H. \& Kleinspehn, K.L., 2003. Incipient continental collision and plate-boundary curvature: late Pliocene-Holocene transtensional Hellenic forearc, Crete, Greece, J. Geol. Soc. London, 160, 
161-181.

Theodoridis, S., 1984. Calcareous nannofossil biozonation of the Miocene and revision of the Helicolihs and Discoasters, Utrecht Micropal. Bull., 32, 1-272.

Van Couvering, J.A., Castradori, d., Cita, M.B., Hilgen, F.J. \& Rio, D., 2000. The base of the Zanclean Stage and the Pliocene series, Episodes, 23(3), 179-187.

Van Hinsbergen, D.J.J. \& Meulenkamp, J., 2006. Neogene supradetachment basin development on Crete (Greece) during exhumation of the South Aegean core complex, Basin Research, 18, 103-124.

Wortel, M.J.R. \& Spakman, W., 1992. Structure and dynamics of subducted lithosphere in the Mediterranean region, Proc. K. Ned. Akad. Wetensch., 95, 325-347.

Wortel, M.J.R. \& Spakman, W., 2000. Subduction and slab detachment in the Mediterranean-Carpathian region, Science, 290, 1910-1917.

Young, J.R., Flores, J.-A. \& Wei, W., 1994. A summary chart of Neogene nannofossil magnetobiostratigraphy, Journal of Nannoplankton Research, 16, 21-27.

Zachariasse, W.J., 1975. Planktonic Foraminiferal Biostratigraphy of the Late Neogene of Crete, Utrecht Micropal. Bull., 11: 1-171. 